\title{
Preschool children's nutrition affects adulthood health
}

\section{Nutriţia la preşcolari influenţează starea de sănătate a adultului}

Ancuța IGNAT ${ }^{1}$, Vasile Valeriu LUPU ${ }^{1}$, Gabriela STOLERIU ${ }^{1}$, Alexandru Bogdan CIUBARĂ ${ }^{3}$, Marc-Andre HELLER ${ }^{2}$, Olympia Evangelia CHATZIGIANNI ${ }^{2}$, Marin BURLEA ${ }^{1}$

${ }^{1}$ Universitatea de Medicină şi Farmacie „Gr.T. Popa“, Iaşi,România

2Student, Universitatea de Medicină şi Farmacie „Gr.T. Popa“, Iaşi, România

3Universitatea „Dunărea de Jos", Galați, România

\begin{abstract}
The growth and development of children is influenced by multiple factors like genetics, general health, physical activity, sedentary, sleep quality and proper nutrition. The disturbance of these factors during the pre-school period can negatively influence the health of the older child and later of the adult. An essential part of pediatrics is prevention. Pre-school care should provide opportunities for promoting healthy behaviours for appropriate physical and psychosocial development.
\end{abstract}

Keywords: preschool children, nutrition, prevention

\section{REZUMAT}

Creşterea şi dezvoltarea copiilor este influențată de factori multipli precum genetica, starea generală de sănătate, activitatea fizică, sedentarismul, calitatea somnului şi nutriția adecvată. Perturbarea acestor factori in perioada de preșcolar poate influența în sens negativ starea de sănătate a copilului mai mare şi ulterior a adultului. O componentă esențială a pediatriei este cea de prevenție. Ingrijirea preşcolarilor ar trebui să ofere oportunități pentru promovarea comportamentelor sănătoase în vederea dezvoltării fizice și psiho-sociale adecvate.

Cuvinte cheie: preşcolar, nutriție, prevenție

\section{INTRODUCERE}

O componentă esențială a pediatriei preventive este reprezentată de măsurarea exactă a creșterii și dezvoltării. Creșterea și dezvoltarea copiilor este influențată de factori multipli precum genetica, starea generală de sănătate, activitatea fizică, sedentarismul, calitatea somnului și nutriția adecvată $(1,2,3)$. Alimentația este un eveniment principal în viața unui copil. Este necesară focalizarea atenției părinților și îngrijitorilor asupra acesteia și, de asemenea, reprezintă o sursă de interacțiune socială prin comunicare verbală și non-verbală. Alimentația, pe lângă aportul de nutrienți, reprezintă și o oportunitate de învățare. Ea afectează nu numai creșterea fizică și sănătatea copiilor, ci și dezvoltarea psiho-socială și emoțională. Nutriția este influențată de cultură, starea de sănătate și temperament (4).

Populația lumii, în special copiii din țările în curs de dezvoltare, trec printr-un fenomen cunoscut ca „tranziția nutriției“. O serie de modificări ale consumului de alimente și ale stilului de viață, statusul socioeconomic și condițiile de igienă determină o creștere accelerată a procentului de copii supraponderali sau obezi, precum și reducerea cazurilor de malnutriție $(5,6,7)$. 
În anul 2010, supraponderalitatea și obezitatea au fost raportate ca fiind de $6,7 \%$ la preșcolarii din întreaga lume. Se estimează că în anul 2020 prevalența acestor tulburări va crește la $8,6 \%(8)$.

\section{Particularități fiziologice ale preşcolarului}

Perioada de la 12 luni până la pubertate este o etapă în care creșterea în greutate și lungime este liniară, mai puțin spectaculoasă, în comparație cu schimbările importante din perioada de sugar și adolescență (9).

Indicele de masă corporală (IMC) este utilizat pe scară largă la nivel internațional ca o definiție a obezității (10). O creștere rapidă a IMC are loc de obicei în primul an de viață. Ulterior, țesutul adipos se reduce (obiectivat de scăderea IMC), consecutiv creșterii în lungime și reducerii dimensiunilor adipocitelor. Momentul de maximă reducere este la vârsta de 6 ani, apoi crește din nou pe tot parcursul copilăriei, fenomen cunoscut sub denumirea de "rebound-ul adipos" al IMC (11). Acest moment are rol predictiv pentru obezitate la adult (12). O revenire precoce este un factor de risc pentru obezitate (13).

În perioada de preșcolar au loc modificări ale proporțiilor corporale. Membrele se lungesc, capul crește mai puțin, iar creșterea trunchiului scade. În această perioadă, greutatea copilului crește cu 2-3 kg/an, iar înălțimea crește cu 6-8 $\mathrm{cm} / a n$. Creșterea greutății și înălțimii variază în funcție de modificările de apetit și de aportul alimentar.

\section{Evaluarea nutrițională}

Statusul nutrițional adecvat reflectă echilibru dintre aport și necesități. Astfel, evaluarea nutrițională reprezintă fundamentul asistenței nutriționale acordate copilului.

Componentele evaluării nutriționale constau în: anamneza nutrițională, examen clinic, antropometrie (greutate, lungime/talie, circumferința craniului, IMC), curbe de creștere standard și de referință și date paraclinice. Factorii care pot afecta statusul nutrițional la copil pot fi reprezentați de boli ale membrilor familiei, evoluția sarcinii, a nașterii, greutatea la naștere, utilizarea de medicamente sau suplimente nutriționale.

Evaluarea nutrițională reprezintă un instrument important de screening pentru evaluarea stării generale a copilului, atât a subnutriției cât și a obezității. Astfel, se pot identifica tulburările marcate de creștere și dezvoltare. Aceasta permite monitorizarea copiilor cu afecțiuni cunos- cute că afectează creșterea (afecțiuni renale, cardiace etc.).

\section{Necesarul caloric}

La preșcolari, recomandările nutiționale încep să se apropie de cele adresate copiilor mari și adulților. Principalele dificultăți sunt legate de aportul alimentar din punct de vedere calitativ și evitarea excesului de aport caloric.

Necesarul caloric reprezintă cantitatea de energie necesară pentru a compensa cheltuiala energetică totală corespunzătoare nivelului dorit de activitate fizică și de a asigura în mod optim creșterea și dezvoltarea. Intensitatea activității fizice variază cu vârsta, fiind mai redusă la copiii între 2 și 5 ani decât la copiii între 6 și 10 ani (9). Necesarul energetic (NE) se calculează după formula: NE (kcal/zi) $=1000+100$ x vârsta (ani) (9).

\section{Intervenții nutriționale}

Există 10 pași pentru o alimentație sănătoasă la copii (14):

- mese relaxante împreună cu familia;

- părinții decid calitatea, copiii cantitatea;

- se oferă alimente din toate cele 5 grupe de alimente în fiecare zi (cereale, fructe și legume, lactate, carne, grăsimi);

- se recomandă 3 mese regulate și 2 gustări pe zi;

- se recomandă $6-8$ pahare $(100-150 \mathrm{ml})$ de lichide pe zi (lapte, apă, suc de fructe foarte diluat);

- se administrează vitamina D;

- se respectă gusturile și preferințele copiilor, aceștia nu trebuie forțați;

- se răsplătește copilul cu atenție, nu se folosesc mâncarea și băutura ca recompensă;

- se limitează mâncarea prăjită, chipsurile, prăjiturile, biscuiții și se interzic sucurile cu zahăr, băuturile acidulate, sucul de fructe, ceaiul, cafeaua, nucile întregi și alimentele mici, rotunde, care se pot aspira;

- se încurajează activitatea fizică timp de cel puțin 3 ore în fiecare zi și aproximativ 12 ore de somn.

Este cunoscut faptul că preșcolarii învață comportamentul alimentar prin obsevație și participare la diverse activități comune, de aceea modelul parenteral și al îngrijitorilor reprezintă o oportunitate ideală de a promova comportamentele nutriționale pozitive. Cercetătorii au demonstrat similarități în diferite aspecte între mamă și fiică privind consumul de băuturi, 
consumul fructelor și legumelor, consumul grăsimilor, mineralelor și vitaminelor. Se recomandă mesele în familie, momente în care copiii sunt încurajați să consume aceeași alimentație sănătoasă ca și părinții $(15,16)$. Părinții și îngrijitorii au un rol vital în dezvoltarea comportamentului alimentar sănătos prin furnizarea de alimente sănătoase. Acestea trebuie să fie accesibile copiilor. Tăierea fructelor și legumelor și servirea acestora ca "finger food“ reprezintă o modalitate de a promova consumul acestora (17). Strategii precum „mănâncă tot" sau „termină tot din farfurie" au determinat creșterea conumului caloric la copil, creșterea consumului de grăsimi, reducerea consumului de fructe și legume, creșterea timpului de alimentație a copilului și creșterea gradului de obezitate (18).

Băuturile acidulate îndulcite cu zahăr și sucurile de fructe sunt frecvent consumate de copii. Aceste au calorii multe și sunt sărace în nutrienți. Există studii care au arătat legătura dintre consumul de băuturi îndulcite cu zahăr și excesul ponderal la copiii mici (19). Deși consumul de sucuri de fructe ( $100 \%$ natural) nu are legătura cu supraponderalitatea, aportul energetic este mai mare la copiii care consumă aceste sucuri. Prin urmare, se recomandă limitarea sucului de fructe $100 \%$ natural la o singură dată pe zi într-o ceașcă (20). Apa este o alternativă la băuturile îndulcite cu zahăr și sucurile de fructe în încercarea de a reduce aportul total de energie (21).

Rezultatele unui studiu efectuat în Oradea pe 316 copii au arătat că alimentația la copii este corespunzătoare, aceștia consumând frecvent fructe și legume, consumul de "fast food" fiind încă necaracteristic (22).

O creștere a dimensiunilor porțiilor este considerată a fi un factor important care contribuie la epidemia de obezitate. La dimensiuni mai mari ale porțiilor, copiii mai mari vor consuma cantități mai mari în comparație cu copiii mai mici (23). Educarea părinților în privința dimensiunilor porțiilor în raport cu vârsta copiilor este considerată cheia în promovarea alimentației sănătoase. De asemenea, se evită utilizarea farfuriilor de aceeași dimensiune cu a adulților, încurajând astfel porții mai mari.

Prin stabilirea rutinei și a meselor regulate la intervale stabilite și limitarea alimentației la trei prânzuri și două gustări pe zi, aportul caloric poate fi controlat. Deseori, la preșcolari cele trei prânzuri nu reușesc să acopere necesarul de nutrienți, de aceea sunt necesare și două gustări din primele patru grupe de alimente. Prânzurile și gustările trebuie spațiate la intervale de timp regulate de-a lungul zilei pentru a preveni înfometarea și tendința de supraalimentare.

\section{Activitatea fizică şi comportamentul sedentar}

Inactivitatea din primii ani contribuie la obezitatea din copilărie și la afectarea dezvoltării fizice, cognitive și emoționale. Un studiu despre impactul comportamentului sedentar la copiii sub 4 ani a arătat că aceștia își petrec până la $84 \%$ din orele de veghe fiind inactivi: imobilizați într-un căruț, într-un scaun de mașină sau în fața unui ecran (24). Asocierile au fost evidente între comportamentul sedentar și adipozitate, sănătatea oaselor, abilitățile motorii, sănătatea psihosocială, dezvoltarea cognitivă și sănătatea cardiometabolică.

Autorii unui studiu efectuat pe 1.314 de copii mici au raportat o asociere între privitul la televizor și creșterea circumferinței taliei. Preșcolarii care au stat la televizor mai mult de două ore pe zi au prezentat o creșterea a circumferinței taliei de 7,6 mm până la vârsta de 10 ani (25). În timpul privitului la televizor, copiii nu sunt doar inactivi, ci sunt expuși la reclamele pentru alimentație nesănătoasă. Un studiu efectuat pe 15.144 de copii din Europa a arătat că cei care primesc prânzul în fața televizorului preferă alimentația bogată în grăsimi și zahăr (26).

Ghidurile recomandă 3 ore de activitate fizică pe zi la preșcolari (27). Cei mai mulți preșcolari din UK au o activitate fizică de 120-150 de minute pe zi, ceea ce înseamnă că aceștia trebuie să mai adauge încă 30-60 de minute pe zi (27). Activitatea fizică poate să apară prin intermediul jocului activ nestructurat, dar poate include, de asemenea, mai multe activități structurate. Activitățile pot fi de orice intensitate (ușoare sau mai energice) (27). Preșcolarii nu sunt capabili să susțină perioade lungi de activitate, de aceea sunt recomandate pauzele.

\section{CONCLUZII}

Practicile parentale și ale îngrijitorilor asociate cu alimentația copilului și activitatea fizică includ: stilurile alimentare, gradul în care părinții și îngrijitorii asigură un mediu sănătos (accesul la alimente sănătoase și facilități de activitate fizică), rolul de modelare a comportamentelor sănătoase, cunoștințe de nutriție. Îngrijirea preșcolarilor ar trebui să ofere oportunități pentru promovarea comportamentelor sănătoase. 


\section{BIBLIOGRAFIE}

1. Berentzen N.E., Smit H.A., van Rossem L. et al. Screen time, adiposity and cardiometabolic markers: mediation by physical activity, not snacking, among 11-year-old children. Int J Obes 2014; 38:1317-23.

2. Jackson D.M., Djafarian K., Stewart J. et al. Increased television viewing is associated with elevated body fatness but not with lower total energy expenditure in children. Am J Clin Nutr 2009; 89:1031-6.

3. Collings P.J., Brage S., Ridgway C.L. et al. Physical activity intensity, sedentary time and body composition in preschoolers. Am J Clin Nutr 2013; 97:1020-8.

4. Liu Y.H., Stein M.T. Feeding Behaviour of Infants and Young Children and Its Impact on Child Psychosocial and Emotional Development. Encyclopedia on Early Childhood Development. Child nutrition. September 2013, 2nd ed.

5. Hernández-Vásquez A., Bendezú-Quispe G., Santero M., Azañedo D. Prevalence of childhood obesity by sex and regions in peru, 2015. Rev Esp Salud Pública. 2016; 90:e1-e10.

6. Popkin B.M., Adair L.S., Ng S.W. Now and Then: The Global Nutrition Transition: The Pandemic of Obesity in Developing Countries. Nutr Rev. 2012; 70(1):3-21.

7. Popkin B.M. The nutrition transition and obesity in the developing world. J Nutr. 2001; 131(3):871s-3s.

8. de Onis M., Blössner M., Borghi E. Global prevalence and trends of overweight and obesity among preschool children. Am J Clin Nutr. 2010; 92(5):1257-64.

9. Ministerul Sănătății. Ghid pentru alimentația sănătoasă. Ed Performantica, Iaşi, 2006.

10. Inokuchi M., Matsuo N., Takayama J.I., Hasegawa T. Official Japanese reports significantly underestimate prevalence of overweight in school children: inappropriate definition of standard weight and calculation of excess weight. Ann Hum Biol. 2009; 36(2): 139-145.

11. Rolland-Cachera M.F., Deheeger M., Bellisle F., Sempé M., Guilloud-Bataille M., Patois E. Adiposity rebound in children: a simple indicator for predicting obesity. Am J Clin Nutr. 1984; 39(1):129-135.

12. Whitaker R.C., Pepe M.S., Wright J.A., Seidel K.D., Dietz W.H. Early adiposity rebound and the risk of adult obesity. Pediatrics. 1998;101:E5.

13. T.J. Cole. Children grow and horses race: is the adiposity rebound a critical period for later obesity? BMC Pediatr. 2004; 4: 6.

14. http://www.infantandtoddlerforum.org/ toddlers-to-preschool/healthy-eating-5/ ten-steps-for-healthy-toddlers. Accesat ultima dată pe: 13.12.2016.

15. Nicklas T.A., Baranowski T., Baranowski J.C. et al. Family and child-care provider influences on preschool children's fruit, juice and vegetable consumption. Nutr Rev 2001; 59(7): 224-235.

16. Addesi E., Galloway A.T., Visalberghi E. et al. Specific social influences on the acceptance of novel foods in 2-5-year-old children. Appetite 2005; 45(3):264-271.

17. Davison K.K., Birch L.L. Childhood overweigh: a contextual model and recommendations for future research. Obes Rev 2001; 2:159-171.

18. Birch L.L. Development of food preferences. Annu Rev Nutr 1999; 19:41-62.36,8,9

19. Hu F.B., Malik V.S. Sugar-sweetened beverage and risk of obesity and type 2 diabetes: epidemiologic evidence. Physiol Behav 2010; 100(1):47-54.
20. Baker S.S., Cochran W.J., Greer F.R. et al. The use and misuse of fruit juice in pediatrics. Pediatrics 2001; 107(5):12101213.

21. Wang Y.C., Ludwig D.S., Sonneville K. et al. Impact of change in sweetened caloric beverage consumption on energy intake among children and adolescents. Arch Pediatr Adolesc Med 2009; 163(4):336-343.

22. Drăgan F., Lupu V.V., Pallag V.V. et al. Rational consumption of nutrients at school-aged children. IOP Conference Series: Materials Science and Engineering 2017; 200(1):1-6.

23. Rolls B.J., Roe L.S., Meengs J.S. Larger portions size lead to a sustained increase in energy intake over 2 days. J Am Diet Assoc 2006; 106:543-349.

24. LeBlanc A., Spence J.C., Carson V. et al. Systematic review of sedentary behaviour and health indicators in the early years (aged 0-4 years). Appl Physiol Nutr Metab 2012; 37:753-772.

25. Fitzpatrick C., Pagani L.S., Barnett T.A. Early childhood television viewing predicts explosive leg strength and waist circumference by middle childhood. Int $\mathrm{J}$ Behav Nut Phys Act 2012; 9(87):1-6.

26. Lissner L., Lanfer A., Gwozdz W. et al. Television habits in relation to overweight, diet and taste preferences in European children: the IDEFICS study. Eur J Epidemiol 2012; 27(9):705-715.

27. Department of Health. UK Physical Activity Guideline. (https://www.gov.uk/government/ uploads/system/uploads/attachment_data/ file/213738/dh_128143.pdf accesată pe 10.01.2016). 